\title{
Leadership Position in Improving Educational Quality at 2 Tanah Abang State Young High School, Penukal Abab Lematang Ilir Regency
}

\author{
Suparmanto $^{1 *)}$, Nur Ahyani ${ }^{2}$, Ratu Wardarita ${ }^{2}$ \\ ${ }^{1}$ SMP Negeri 2 Tanah Abang, PALI, South of Sumatera, Indonesia \\ ${ }^{2}$ Universitas PGRI, Palembang, Indonesia \\ *Corresponding author.Email: suparmantodiana@gmail.com
}

\begin{abstract}
One of the main agenda currently under the focus of the government is to constantly improve the standard of education in Indonesia. Many aspects obviously have an effect on improving education quality. However, the professionalism of leadership and the managing skill of school administrators is one of the most important contributions to attempts to increase the standard of training. The main focus of this study is on the lead role of SMP Negeri 2, Tanah Abang, PALI Regency, in improving standard of education. The aim of this research was to identify the main leadership position in improvement of education quality, to describe SMP Negeri 2's plan to improve quality and to outline help and inhibitor factors to implement this strategy. the main aim of this study was to improve quality of education. This investigation employs a holistic approach and a form of case analysis. Techniques in data collection consisted in observation, methods of reporting, and interview methods. The results showed that leadership improved educational quality.
\end{abstract}

Keywords: Role of Leadership, Quality of Education, School Management

\section{INTRODUCTION}

Efforts to improve human resources have been carried out optimally by the government, and the National Education System Law No. 20 of 2003. Legally speaking, Indonesia already has a strong foundation for implementing quality education.

Providing education certainly requires the contribution and active participation of human resources involved in education. This is explained in Article 1 paragraph 23 that educational resources are utilized to implement education, consisting of education personnel, society, costs, facilities, and infrastructure.

The law provides a clear picture that education implementation requires adequate facilities and infrastructure and requires more professional education and educational personnel.

The principal is also an educator and an educational staff who has an essential role in the implementation of education and teaching in schools.

As an educational staff, school principals must have an important task in managing school administration to be advanced.
According to explains that the principal's role as an administrative staff can be seen in administrative tasks and processes, namely, administrative tasks, including staff, student affairs, school leadership, community, teaching and development curriculum, school finances, school buildings, and facilities.

The administrative process is including problem identification, diagnosis, problem-solving, determining goals, making decisions, planning, organizing, coordinating, delegating, communicating, and evaluating [1].

From the description of the principal's duties in previous paragraph, there are several major duties as school administrator if defined one by one. The principal must become a successful leader as his hard labour has an important impact on teacher and student success as the leadership of the efficient principal has.

According to Stronge [1] mentions There are several definitions as follows: Several basic aspects of school leaders' behaviours and roles that specifically relate to leadership activities: The role played by the principal in the success of students includes teaching leadership, the attitude of education, the management of human 
resources, the assessment by professors, corporate management, communications and communities.

Improvements in governance and leadership are necessary by careful management of social needs and growth. The reason is that school management inspires schools, allows them to improve the quality of schools so that the vision and mission of their dreams and the school goals set can be realized. The achievement should be achieved through school-based management, and it is possible to compete to achieve it.

All of that depends on the school's conducive climate to bring up a variety of creativity of educators and education personnel and students in schools, not waiting for top-down policies but conditioned to emerge by involving stakeholders (bottom-up). The leader has a key role, and in school management must be active, creative, innovative, and have the courage to take risks and be accountable for them.

They continuously conduct School Self-Evaluation (EDS), review of situations and capabilities, shortcomings, prospects and risks (SWOT analysis) in managing the school's existing conditions. Emphasis on different school abilities depends on how school management influences and empowers human resources and other resources to achieve the set standards.

Commitment is a strong intention and full sincerity to carry out the duties and obligations that it carries. This commitment should be owned by every school member who is involved in an activity at the school to make the activities entrusted to him successful.

The performance of educators, staff, and training and studying students runs well if it is supported by good management and leadership as well as stakeholder participation, which combines the three concepts, namely: empowerment, creativity, and commitment.

Leaders act to help others in an organization with the abilities they have to achieve goals. The art and capabilities of individuals with their ability to compel others to perform such tasks for predetermined purposes are leadership or leadership [2]. Mulyasa [3] states leadership can be defined as an activity to influence people directed towards achieving organizational goals.

According to that, leadership is the ability to plan, organize, implement, and mobilize all available resources to achieve predetermined educational goals. Kartini, et al [4] noted that the performance of teachers at the same time has a significant impact between lead, instructional oversight and professional competence.

Leadership or leadership means being a leader, the power of leading, or the qualities of a leader. It means That leadership is a leader's power or quality to direct something that leads to achieve objectives. Leadership, the capacity that an individual has to control others in order for aims and priorities to be achieved, is an integral aspect of management. Management comprises management, management and other roles including strategy, organization, supervision and assessment. Leadership and management are two different terms. However, it has a meaning that is not much different. Leadership is directed at creating effective results, while management is more directed at creating procedural processes.

On the basis of the above, leadership can be inferred a trait possessed by a person because the task he is carrying out tries to influence his followers to obey something that is their lead's instruction. In this case, argue that organizations with good leadership are easier to lay the foundation of trust in their members, and vice versa. Thus, the principal's leadership also needs to position himself as someone who has influence on all school members and provides motivation to be able to work well the school attempts to accomplish its vision, mission and objectives.

Leadership in education is the capacity of the chief to control the elements of school to accomplish the shared goals.

The main element is one of the most important ingredients for enhancing the standard of education. The role function in leadership and management, as stated in PP. 28 of 1990, article 12 paragraphs 1, states the principal shall be responsible for the operation of instructional programs, management of the classroom, promotion of educators and staff, use of resources and the maintenance of equipment and facilities.

There are three main elements in the leadership function. Educational leader as a manager which includes functions as administrator and supervisor. Educational leaders as leaders include functions as innovators and motivators. Educational leaders as educators.

According to states that in general, educational leaders have three main roles, namely leadership, managerial, and curriculum-teaching

\section{METHODS}

The analysis used in this analysis is a relational technique that generates descriptive data from individuals and the behaviour they can see through the written or spoken word. Qualitative approaches provide analysis processes that generate qualitative evidence containing the expressions or notes of the informants or their observable behaviour.

While this kind of analysis is a case study, it looks in detail at how leadership plays a role for SMP Negeri 2 Tanah Abang in enhancing professionalism. Case studies were selected because the case study was designed for study, explanation and interpretation of the 
case without interference by external parties in the natural framework according to Baidhowi in Agus [5].

This research uses observational data collection methods, documentation methods, and interview methods. When these techniques are carried out continuously in the field to obtain comprehensive and accurate data.

The method of observation is "observation or recording phenomena of the things being investigated". This method is used by researchers using observation techniques in order to observe realistically about leadership position (the main one) in enhancing education quality in SMP Negeri 2 Tanah Abang. According to J.P Spradley, there are three components that can be observed, namely space, actors, and activities (activities).

Data analysis in qualitative research at SMP Negeri 2 Tanah Abang was carried out before going into the field, observing, interviewing, collecting documents during the research implementation, and after completing research in the field. The third analytical activity is to draw conclusions and verification.

\section{RESULTS AND DISCUSSION}

\section{1) Improving the Quality of Education}

The book Development of School Management describes quality of education in two ways: absolute quality and relative quality. Absolute quality is the quality in the sense of institutional provisions that cannot be negotiated or absolute, determined unilaterally by the producer or service. Meanwhile, relative quality is defined as the quality determined by consumer tastes. These two views on quality imply that the goods or services produced must always prioritize the match between quality in absolute and relative perspectives. This means that every good or service produced must satisfy customers and meet the specifications of the manufacturer. In essence, absolute quality feels comfortable with the teacher's learning services with the school's various resources to meet customer satisfaction. The organization has a direction and an overview of something that must be done when producing goods or services.

The quality of education is an indicator to see the productivity of the results (output). This is closely related to management. School as an organization in improving quality, can pay attention to one aspect and all aspects of the school. Because a good process influences a good product, a good process is influenced by a good organization or management, while good management is influenced by professional leaders and is supported by a joint commitment in a team.

An education leader or manager must be able to spark new ideas in carrying out his work to make an innovative change from his thinking, which wants changes and advances in school achievement in quality, not only depending on the boss. The most important thing in management that wants change is the birth of new ideas from managers that can encourage the development of performance of human capital and improved school quality. One of the efforts to overcome the problem is by studying the principal's emotional intelligence as a manager [6].

In general, principals should "lead from the centre": be democratic, delegate responsibilities, enhance policymaking and work together to unite pupils, teachers and parents. In this situation, this means that the boss must be in the centre of the organisation (participatory).

To identify the low quality of education from a system point of view, namely problems that exist in the input component, process, educational outcomes (output), and education outcomes [7].

Educational input is anything that must be available which includes human resources and other resources and it's essential to take part in the process. The input readiness is needed to make the process run smoothly. The highly poor input output can be calculated by the input readiness and the greater the input readiness, the higher the input readiness. Education results are the success of the classroom, including the achievement of schools as a result of school procedures. The consistency, reliability, efficiency, efficiency, creativity and quality of life and work ethic of the school's success can be calculated. If the school's success, especially student achievement, shows high academic success, the school performance is of high quality/quality, nonacademic achievement, and good personality. School quality is influenced by interrelated activity stages, for example in planning, implementation and supervision.

When viewed from a systems point of view, the issue of the quality of education has a strong link between problems in education input, processes, outcomes, and impacts. The results of lower quality education influence education, which is not in accordance with stakeholders' expectations. Poor quality education outcomes are influenced by processes that are less qualified. The less qualified education process is influenced by educational inputs that do not meet standards.

Improving education quality, the problem that must be resolved is how each input of education can be met according to standards so that the educational process can be carried out with quality and produce education graduates who meet standardized qualifications. The results of education have a very big impact on the nation's welfare and state. Low-quality education is mostly due to the inadequate professionalism of human capital in education and other resources that are not capable of providing adequate training facilities to students. In trying to increase the standard of education, we have to chart the root of the problem. 
The quality of education services can be categorized based on the system view, namely output, process and input. Based on this view, the categories of school quality simply include the quality of the results, processes, and quality of the process's supporting aspects. The quality of results is the quality of educational outcomes that are felt primarily by students as a tangible form of the learning process. Process quality is quality as seen from the extent to which students feel comfortable with the teacher's learning services with the various resources owned by the school.

Input quality is the quality that appears from various inputs for the learning process, which includes: teacher quality, curriculum quality, facility quality, student quality and other things that contribute to the learning process.

Substantively, the quality of education is described as a complex state related to the expected products or outputs, utilities or facilities, persons, processes and the environment. There are many facets of the requirements to determine the standard of education: output, services, human resources (teachers), processes, and the environment according to community expectations.

\section{2) Management of School Quality Improvement}

Cites Stoner, Fremaan and Gilbert's view [8] that the administration of corporate members is a planning, coordination, leadership and oversight mechanism and uses all existing organizational tools to accomplish organizational objectives.

There are strategies of management that are full of leadership values, in which to guide, influence, oversee and organize each other components to accomplish objectives.

Education management is very important because it is based on several assumptions that: first, the quality of human resources (HR) is the key to the nation's competitive ability, secondly, education is the most effective effort to improve the quality of human resources, third, only quality education can produce quality human resources, fourth, quality education must be provided with quality education management.

Meanwhile, according to Mulyasa [3], the term management is the creation of a community of people's cooperative activities in the achievement of predetermined educational objectives. The group's operations are governed by the planning, organization and management process as a process for turning vision into reality.

School management is defined as a management model that provides greater autonomy or independence to schools [9]. The word 'school management' is a version of the term 'school-based management' that first emerged in the USA when people questioned the importance of education to the needs and growth of local communities.

The administration of schools is a modern training model, including increased school-level control [8].

From the description above, it can be concluded that Schools are more independent in operating their schools and have a higher degree of commitment than schoolinterested organizations in determining objectives, preparation of strategies, execution plans and assessment of quality progress, versatility in management of school services. Schools are the primary entity for education administration, while those above are the Education Office, the Education Provincial, and the National Education Department to become school supporters and servants, especially in quality improvement management.

According to Danim [8] to achieve the MBS concept goals, education providers in schools must be guided by the main principles underlying the implementation of SBM. Focus on quality. Bottom - up planning and decision making. Transparent management. Community Learning. Continuous quality improvement

The principal in managing the school should refer to these principles. Based on these principles, school residents increase a sense of belonging which results in an increased sense of responsibility and high dedication from the community

Evaluation of school success problems must be carried out at the beginning of the program and at the end of program implementation to improve education quality by conducting analysis continuously. The school is the primary unit for educational administration, while above it is the units are the school's support and service units in terms of quality improvement management. School success evaluation is a process to compare the conditions that have been achieved with the targets to be achieved in the annual work plan. The process of evaluating the success is preceded by monitoring the processes and results achieved. Then the monitoring results are processed and compared with the work program targets. The evaluation of school success is an important material as input for follow-up and continuous improvement which is the main principle in the education quality assurance system.

School-based management has featured that schools must understand if the implementing of school-based management is to be fruitful. Management focused on schools' characteristics are closely related to the characteristics of an effective school, meaning that school-based management is a forum, while effective school is its content which includes input, process and output.

In his description, it will start from Output is important because output, while processes are less 
important than output, and input is less important to output [10]. Input is the most important stage.

The school's predicted performance. School performance is the school achievement created by school learning and management. Output is generally graded in two, i.e., output as university accomplishment and output as non-academic achievement.

The example youth research tournaments, mathematics contests and others represent the outcome of academic achievements. Non-academic performance results for example: character/character, positive social behaviour like drug free, integrity, good co-operation, high solidarity, high empathy, discipline, skills, the performance of athletics, arts and scouting. Nonacademic achievement output turned out to have a big influence on academic achievement.

The management of education personnel, especially teachers, is the soul of the school and the school is the container. Management of education personnel starts from needs analysis, planners, development, job evaluation, work relations, and remuneration. Educational personnel development must be carried out continuously in light of the rapidly developing advances of science and technology. Highly committed, capable and capable of carrying out their duties properly is one factor for the success of school-based management.

\section{CONCLUSION}

The principal who has played his leading and managerial positions well and his other roles is a powerful leader in improving education efficiency.

A leader should be tough, hardworking and smart, creative, innovative, committed, and try to set an example for the school community.

The strategy carried out improving school standards through school management can be seen from school principals, teachers, employees, and stakeholders in collaborating and establishing communication in carrying out every activity that is their duty and responsibility to achieve the expected educational goals. This performance is carried out by developing strategies to improve academic standards in these schools by conducting: environmental analysis, analysing gaps in current school conditions and expected conditions in the medium and short term, gradually addressing gaps, implementing programs and monitoring and evaluating these programs gradually continuous for further action.

\section{ACKNOWLEDGMENTS}

Our deepest gratitude goes to Teachers in SMP Negeri 2 Tanah Abang, PALI, Chancellor of Palembang PGRI University, Director of the Postgraduate Program of PGRI Palembang University and the Education Management Study Program of PGRI Palembang University, who have supported us in doing this extraordinary thing. This project is funded independently. We also want to thank our Education Management friends who helped us a lot in a short time frame to complete this project.

\section{REFERENCES}

[1] Stronge, J. H. (2013). Kualitas Kepala Sekolah Yang Efektif, terjemah Siti Mahyuni [Quality of Effective Principals, translated Siti Mahyuni]. Jakarta Barat: PT. Refika Aditama.

[2] Syaefullah. (2012). Manajemen Pendidikan Islam [Management of Islamic Education]. Bandung: CV Pustaka Setia.

[3] Mulyasa, E. (2009). Menjadi Kepala Sekolah Profesional [Become a Professional School Principal]. Bandung: PT Remaja Rosdakarya.

[4] Kartini, D., Kristiawan, M., \& Fitria, H. (2020). The Influence of Principal's Leadership, Academic Supervision, and Professional Competence toward Teachers' Performance. Education and Training for Strengthening Principal to Effective Schools. International Journal of Progressive Sciences and Technologies (IJPSAT), 20(1).

[5] Agus, S. (2001). Teori dan Paradigma Penelitian Sosial [Social Research Theory and Paradigm]. Yogyakarta: Tiara Wacana Yogya.

[6] Rohiat. (2008). Kecerdasan Emosional Kepemimpina Kepala Sekolah [Principal Leadership Emotional Intelligence]. Bandung: PT Refika Aditama.

[7] Triyo, S. (2008). Manajemen dan Kepemimpinan Pendidikan [Educational Management and Leadership]. Bandung: Refika Aditama.

[8] Karwati, E. (2013). Kinerja dan Profesionalisme Kepala Sekolah, Membangun Sekolah Bermutu [Performance and Professionalism of Principals, Building Quality School]. Bandung: Alfabeta.

[9] Danim. (2013). Pengelolaan Pendidikan [Education Management]. Yogyakarta: Multi Pressindo.

[10] Husni, K. (2015). Manajemen Perubahan Sekolah [School Change Management]. Bandung: Pustaka Setia. 